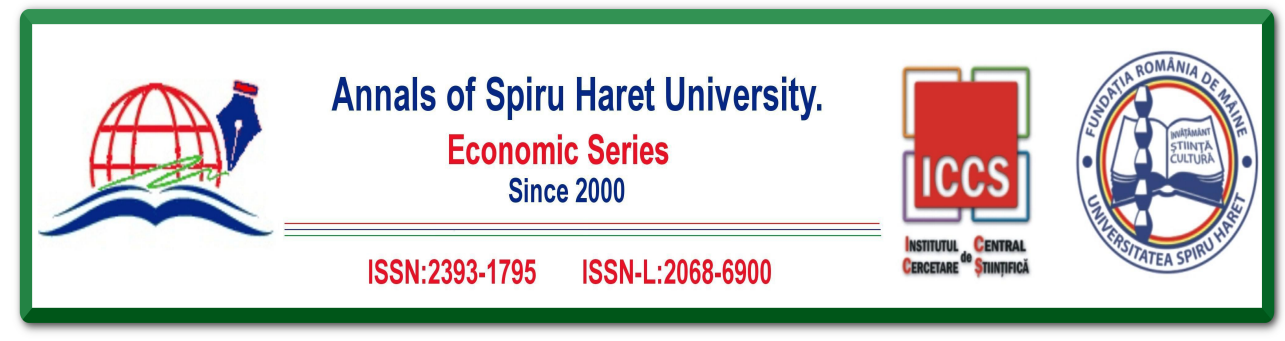

Issue 4/2019

\title{
AN ANALYSIS OF INNOVATION AND CULTURAL DIVERSITY IN THE CHALLENGES AND PERSPECTIVES OF LOCAL COMPANIES' DEVELOPMENT: AN EXAMPLE OF AZERBAIJAN
}

\author{
Mahammad JABRAYILOV ${ }^{1}$ \\ ${ }^{1}$ Master student in Management, WSB University, Poland, \\ Tel.: +994.70.767.00.88, E-mail address: cabrailoff@mail.ru
}

How to cite: JABRAYILOV, M. (2019). "An Analysis of Innovation and Cultural Diversity in the Challenges and Perspectives of Local Companies' Development: An Example of Azerbaijan." Annals of Spiru Haret University. Economic Series, 19(4), 127-139, doi: https://doi.org/10.26458/1948

\begin{abstract}
The role of innovation is crucial for countries and businesses to gain competitive advantage. The key to success in the competitive process is to have a culture of innovation. The purpose of this study is to identify the link between innovation and cultural diversity in company management, which is one of the most important sources of competitive advantage, and to explore the role they play in company management. In this regards, a comprehensive review of innovation, cultural diversity and organizational culture has been conducted and links are established. The study concludes that innovation and cultural diversity have a major impact on innovation in companies and services.

This study seeks to provide a comprehensive overview of the role of local innovation companies in the development challenges and perspectives, while providing insights into the concepts of innovation and cultural diversity. Research work can be considered as a good source for experts, researchers, and scientists working in this field.
\end{abstract}

Keywords: innovation; cultural diversity; organizational culture; firm; workplace; creativity. 


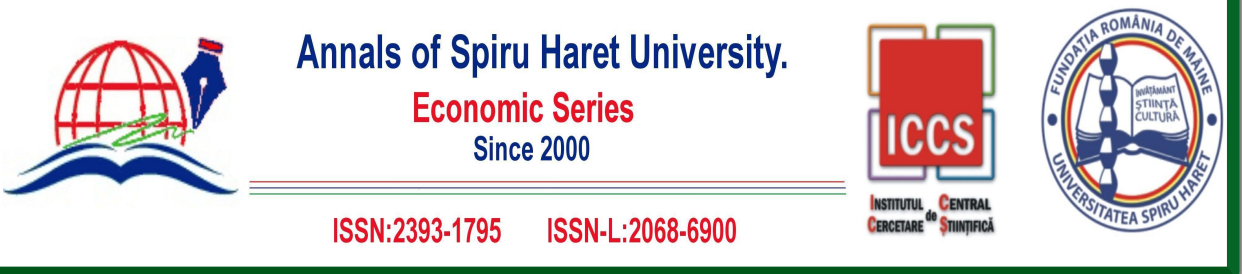

Issue 4/2019

JEL Classification: M14

\section{Introduction}

Cultural diversity or innovations are one of the most important factors in the development of our modern world. In the context of dynamic structural changes, the success of individuals and organizations, nations and societies is largely dependent on their ability to create, understand and use different kinds of innovations, such as food and technology, social and cultural.

In addition, innovation is an important factor in long-term national economic growth and policy interference [Romer, 1990a; Schumpeter, 1962]. Nobel Laureate Linus Poling; The importance of having different ideas in creative expression with popular expression: "The best way to get a good idea is to have lots of ideas." The idea of this expression is similar to the fact that most literature on divergent research needs different opinions, but there are different opinions.

The culture of innovation has been defined as the core value that supports innovation at the enterprise level and embraces accepted practices for innovation. Most organizations accept diversity in their perspectives, workplaces or organizations to be more creative and open to change. Increasing and improving workplace diversity has become an important issue for management in recent years because of how the workplace has changed.

There is a need for the Republic of Azerbaijan to create an independent economic system after independence and to integrate this system into the global economic system. The development of the economy by innovative methods is crucial for ensuring economic independence in the country.

In this study, a large number of employees from different companies and service providers operating in Azerbaijan were selected. An application form was used to collect data. Respondents generally agreed that a diverse and inclusive workforce would bring different perspectives to strengthen a company's innovation strategy.

Thus, this study, with an introduction, 3 main sections, a conclusion and a literature review, aims to assess the relationship between diversity and innovation in an organizational context and to explore whether diversity is the result of increased productivity through increased innovation. It clearly explores the link between diversity and innovation. It is assumed that such a relationship flows through increased productivity and economic growth, as has long been understood in the literature. 


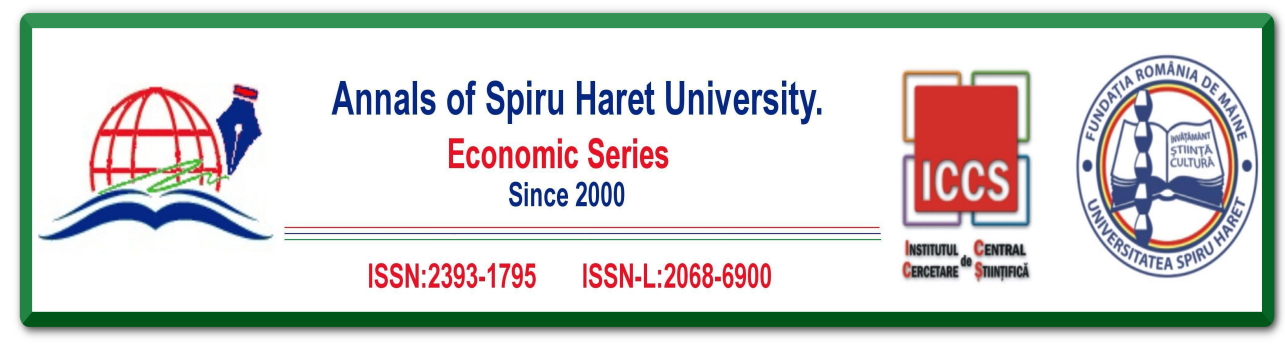

Issue 4/2019

In this research, I reviewed previous studies and concepts and discussed some of the literature on theoretical aspects of cultural diversity and innovation in the workplace.

\section{Research Methodology}

This study can be defined as conducting research to gain additional information or ideas to contribute to a particular understanding and knowledge in a particular discipline. [Myers, 2009] This process involved a combination of research and analysis. During the process of answering research questions, the study is based on primary and secondary sources of information. Two companies with the first source received an email interview with questions regarding their experiences and experiences of working with the multicultural workforce. A second source of information on the diversity of work in the two companies is collected on the Internet.

\section{Theoretical Approaches to the "Innovation" and "Cultural Diversity"}

Understanding of the term of "innovation" and "cultural diversity"

Innovation is the application of highly efficient innovation, new and improved products, technological processes, as well as organizational, technical, financial and economic and other aspects of public relations as a result of intellectual activity, discoveries and inventions. The term innovation comes from the Latin word "innovato", which means "renewal" and "improvement." The term has been used in scientific research since the $19^{\text {th }}$ century. The concept of "economic innovation" became known to the scientific community in the early $20^{\text {th }}$ century in the work of the Austrian economist Joseph Schumpeter's Theory of Economic Development. [Schumpeter, 1934]

There are many definitions of the concept of innovation in the literature. In short, it can be defined as the process of transforming innovative ideas into valueadded outputs.

Innovation - industrial consulting services, research, design and construction, accounting and analytical works, design feasibility study, production, organization and management, product realization. The concept of "innovation" envisages a new rule, a new method, a new product or technology, a new event. Innovation is the process of using innovation associated with the acquisition of innovation, its reproduction and implementation in the material environment of society.

But, underlining that not everything that is new can be considered an innovation, perhaps it will be an important step in understanding the scope of innovation, 


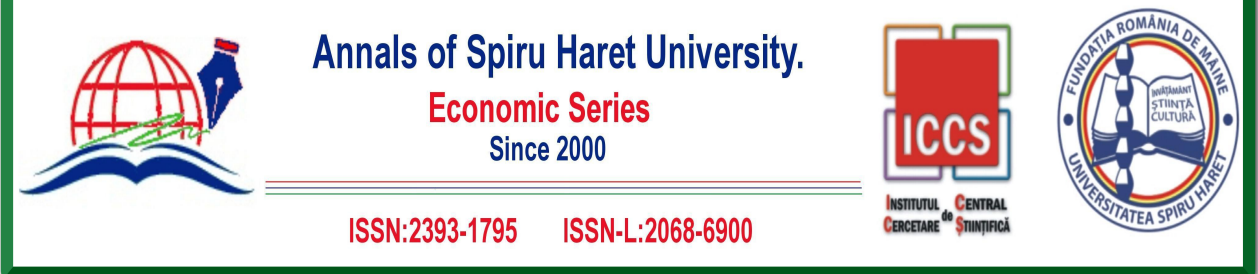

\section{Issue 4/2019}

because the basic dynamics of innovation are not everything that is new, but innovations that are transformed or transformed into an economic and social added value.

In other case, Gonzales and Denisi gave a basic definition for diversity: "differences between individuals on any personal attributes that determine how people perceive one another". Their definition is very general and not categorized. [Gonzales \& Denisi, 2009] Richards and Kirby offered one of the most limited definitions; they claimed that the diversity is defined by the subset of demographic characteristics including gender, race-ethnicity, and age. [Richards et al., 1999]

\section{Approaches to the relations between innovation and cultural diversity}

However, in many of today's academic studies [Levitt, 1960; Varga, 1998; Fagerberg, 2004; Etzkowitz, 2008; Chavushgil, 2009; Christensen \& Eyring, 2011] focusing on mobilizing the scientific potential of universities for innovation, and innovation has been tangentially based on imagination, cultural change, social change and organizational change; commercialization, innovation and utility. Beside it, culture includes many elements that can increase or decrease the tendency to realize innovation. However, when defining innovation culture, it would be wrong to consider culture in isolation or, on the contrary, simply define organizational culture as the only factor that will cope with the lack of innovation in the organization [Ahmed, 1998].

In their studies, which showed the impact of country culture on innovation, although there is a significant difference between the patent density in Europe and culture, Kaasa and Vadi found a relationship. [Kaasa \& Vadi, 2008] However, Shane (1992) showed a positive relationship between patented inventions and individuality, one of Hofstede's (1980) cultural dimensions. Other studies suggest that countries with a lower power have more advantages in terms of innovation potential.

Goffee and Jones focus on two types of human relationships and their implications for organizations within the framework of organizational culture. The first of these relationships, sociality, is about the degree to which the people in the organization can establish sincerity in their relationships with each other. Ideas, attitudes, interests and values are shared with the establishment of sincerity [Goffee \& Jones, 1996].

Robbins and Coulter found that one of the three main dimensions that will trigger innovation is cultural variables and they found that these variables were acceptance 130 


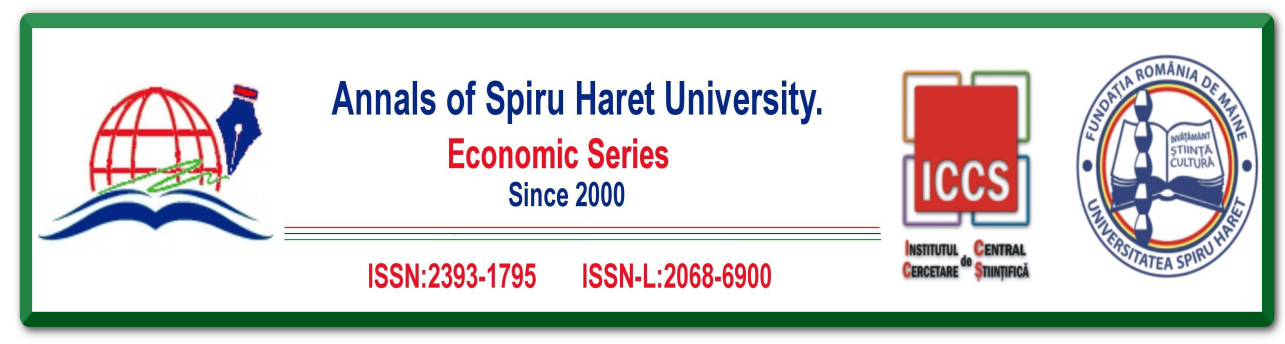

Issue 4/2019

of disputes, tolerance to impractical practice, low external control, tolerance to risks, tolerance to conflict, outcome focus, open system focus and positive feedback. [Robbins \& Coulter, 2012]

\section{Impact of Diversity on Innovation in Firm Level}

Continuous monitoring of innovations and the successful implementation of these innovations in gaining competitive advantages are becoming more and more important as a skill that today's organizations are trying to have. Because of innovation, organizational competitiveness is a variable that plays a key role in providing efficiency and efficiency [Osterloh \& Frey, 2000].

Culture is an important resource that enables businesses to compete with their competitors in the long run and is a variable that affects employee behaviour and motivation [Wiener \& Vardi, 1990]. Leaders are believed to be effective in the development and change of organizational culture [Kilmann, 1985]. Therefore, employees are expected to exhibit attitudes and behaviours within the framework of the values established by the organizational culture and the leader.

In development culture; growth, encouragement, creativity and diversity are important motivation factors. Efficiency criteria in enterprises with this culture growth includes the development of new markets and the acquisition of resources [Deshpande \& Webster, 1989].

The interaction between diversity and innovation in organizational settings is complex and sometimes challenging. Diversity can be defined in six clear demographic strips in terms of policy and law: gender, age, race and ethnicity, sexual orientation, religion and belief, and disability. Learning styles and qualifications of individuals and even communities include different knowledge acquisition and communication styles, educational history, personal skills, professional skills and functional expertise.

While ongoing benefits outweigh the initial shortcomings, cultural diversity is good for the team. [Nielsen, 2010] Cox and Blake stated that cultural diversity influences six direct aspects of organizational effectiveness, including creative, innovative challenges, cost, human resource mobilization and problem solving, organizational flexibility and marketing advantages. [Cox \& Blake, 1991]

The study shows that the diversity has positive links with firm performance. Some research show that the company has direct relation with different measures, for example, functional font, age, time and diversity.

Furthermore, the benefits of increased innovation were seen as a key argument in promoting workplace diversity. There are several approaches about diversity by 


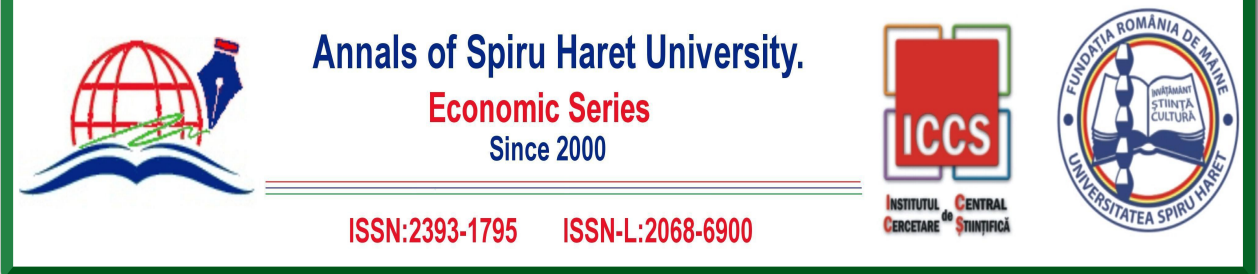

\section{Issue 4/2019}

firms. Although one company suggested that it was not important and two other large companies suggested that diversity-led innovation was the single-most important driver.

Generally, all companies and firms may suffer from the negative impacts of diversity on trust and communication issues, but in many cases this negative impact over time exerts positive effects of diversity. This means that young companies and firms can be more difficult to bring different teams together. Research shows that there is a data gap in this perspective, and there are no studies that directly test the effects of diversity and innovation at the firm level.

\section{Impact of Different Cultural Factors on Innovation}

Culture is a system of values consisting of many elements that take shape of the individual's way of life over time, shaped by the environment in which people live. Culture is a common characteristic of societies that has been formed as a result of centuries of accumulation of value, although there are very different definitions of culture in organizational behaviour literature: culture; emerging and shared through generations of communities' common experiences; values, beliefs, identities, interpretations or meanings of important events [https://globeproject.com/study_2004_2007].

Organizational culture elements, which provide clues about the basic characteristics of organizations, are important for all stakeholders. For example, employees recognize these elements in the organizations they are working with or plan to work with and exhibit appropriate behaviours.

Gandotra (2010) defined innovation culture as a culture associated with organizational structures and processes that make innovation a daily business. Innovation culture determines how creativity, risk taking, entrepreneurship and knowledge and ideas are encouraged. The culture of innovation enables the formation of norms that help organizational members develop behaviours that support, not hinder, innovation activities.

Culture that supports innovation has the characteristics of creativity, risk taking, independence, teamwork, solution focus, communication, high confidence and speed in decision-making [Dobni, 2008].

In addition, Dobni stated that innovation culture has four general dimensions. The first is the intention to be innovative, the second is the infrastructure that provides support for advancing innovation activities, the third is the information and 

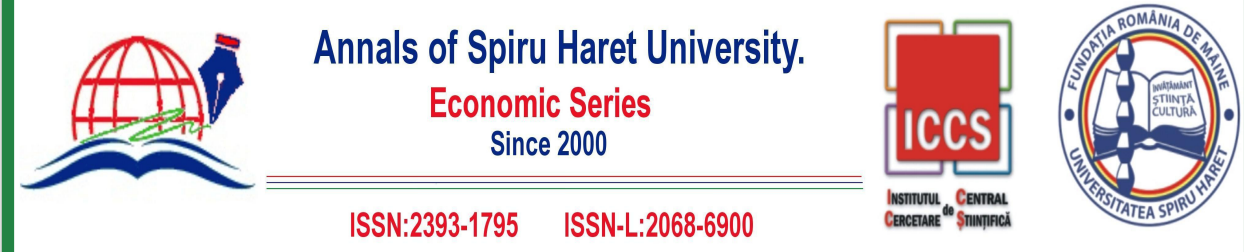

Issue 4/2019

orientations necessary to support the ideas and activities of the employees, and finally the environmental dimensions to support the implementation [Dobni, 2008].

As a result of the information obtained from the studies examined, it is possible to list the characteristics of organizational culture that has a positive impact on innovation, namely the characteristics of innovation culture as follows:

- To show adhocracy culture type of organizational culture (innovation, vision, new resources are important, creativity-oriented);

- Realization of organizational learning;

- Ensuring participatory decision-making process;

- Open-minded managers;

- The leader can easily express his vision;

- Encourage taking risks and accepting uncertainty;

- Creating a competitive, performance-oriented culture;

- Giving importance to group and team work;

- Customer orientation;

- Learning from failure;

- Making change;

- Rewarding;

- Supporting the individuality and independence of employees;

- Importance of both internal and external communication.

\section{Practical Analysis of the Impact of Cultural Diversity on the Management of Local Companies}

It should be noted that the business environment where diversity is most vivid is itself. As a result, it is more appropriate to explore cultural diversity in the work environment. The basis of my research is that the work environment is an area where people from different cultures, customs and traditions apply, work, or have clients.

As a conducive environment for people with different values to come together and conduct a general survey, I preferred the hotel environment for a practical part of my release and found some results in doing research in the hotels of Azerbaijan (Caucasus "Qafqaz" Hotel and New Baku Hotel). In both hotels, the survey was based on the following questions:

1. How old are you?

2. Name of the organization / enterprise you work for? 


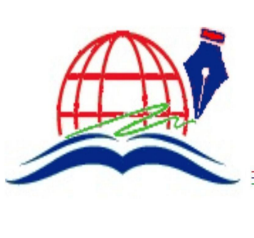

Annals of Spiru Haret University.

Economic Series

Since 2000
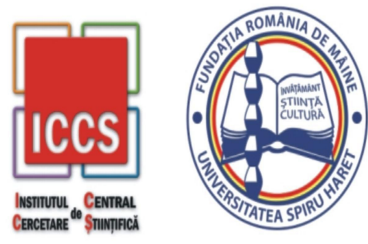

\section{Issue 4/2019}

3. Are the aliens you most often encountered in your organization?

4. What challenges do you face when working with people with different cultural values?

5. What do you think is the advantage of spending time with people who have different customs?

6. What is the challenge of spending time with people who have different customs?

7. What are the benefits of working with outsiders in an enterprise?

8 . Which culture would you most like to adapt yourself to?

The study found that the hotel's employees are between 25 and 40 years old in each hotel. The results of the survey on the hotel workers reflect the statistics of foreigners in this way:

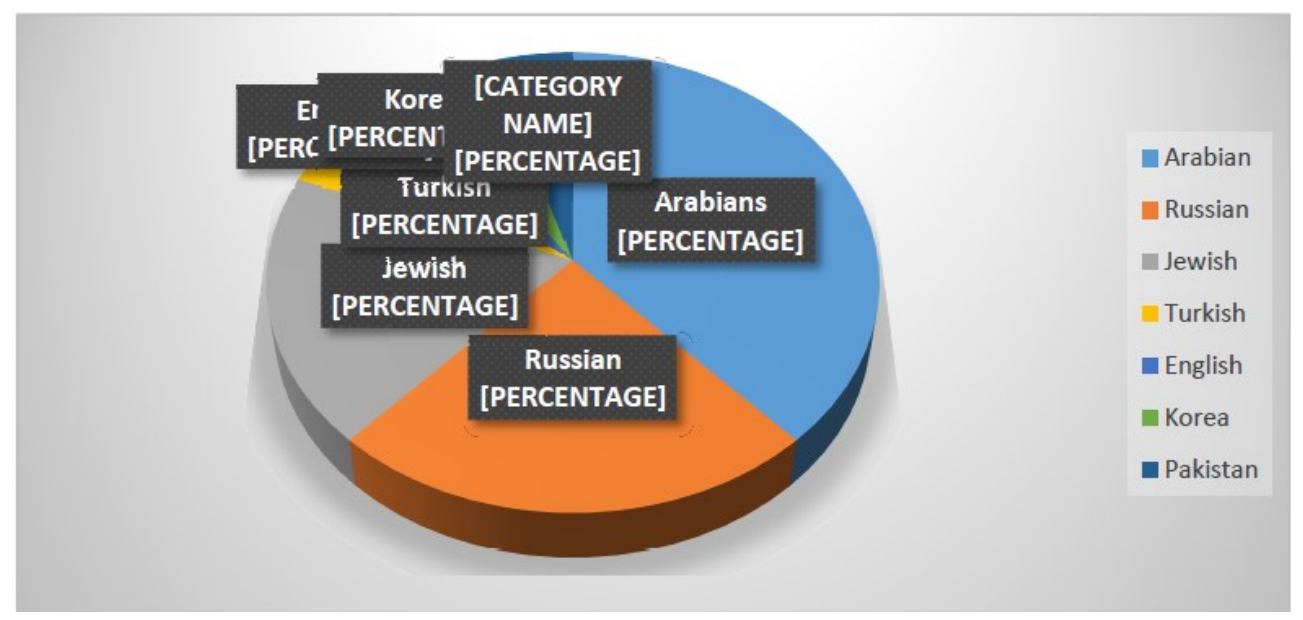

Fig. 1. Statistics of Foreigners at the New Baku Hotel

Based on the results of the survey, almost all of the difficulties encountered during communication and work with foreigners come from a non-complicated format. But sometimes we can get unexpected surprises. The main issue is that there are language restrictions when communicating with foreigners. According to the lady who works at the registration desk in one of these hotels, sometimes foreigners can only request hotel staff to speak their language, even though they have alternative language skills. 


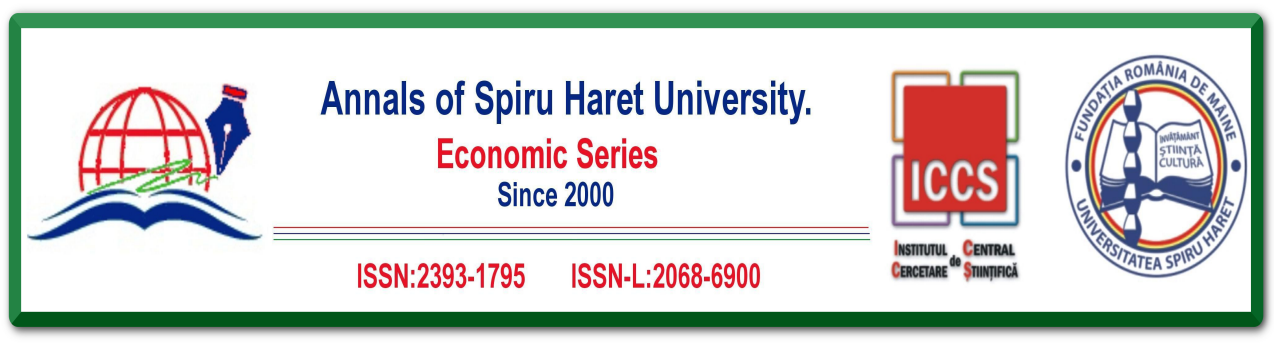

Issue 4/2019

According to her approaches, for example, Italians often speak their language, refuse to speak English, and try to solve the English language problem in the event of a misunderstanding. Some foreigners do not speak a language other than their own language. This also complicates hotel staff. The staff also noted that foreigners are more demanding and more serious about work and services.

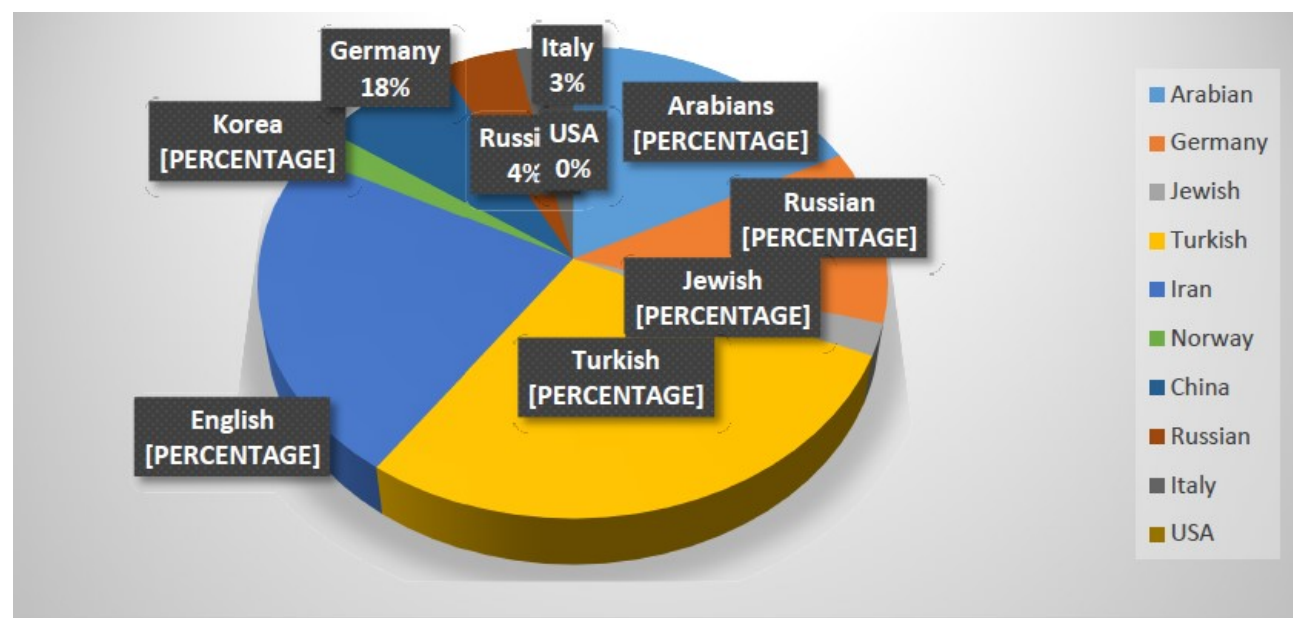

Fig. 2. Statistics of Foreigners at the Qafqaz Hotel

Although it is simpler for foreigners to be more kind and friendly in their communication, this kindness and simplicity does not reflect any problem that may arise from work and service.

As we know, staff in the hotel environment is providing services to foreigners and local citizens. However, it is important to note that it is also possible to employ people of different nationalities within an enterprise. Based on the answers to the questions asked to identify the effects of such activities, summarizing the opinions of the hotel staff, we can conclude that there are both pros and cons to working with foreigners within an enterprise. So, according to the survey results among staff members in both hotels, foreigners are treated more seriously and responsibly. They hand over their work on time and do not allow any delays. They also monitor the progress from beginning to end. Such features make them a valuable employee. They 




\section{Issue 4/2019}

become more understanding, patient and open-minded. They express instances or situations they disagree with immediately and try to find a solution. On the other hand, they are quite demanding. Sometimes the requirements can go beyond the capabilities of the enterprise. Also, their openness is not welcomed by business executives and sometimes by customers. Another problem, of course, is related to the cultures of other people who work in the same environment in the same enterprise. Such situations can lead to conflicts. There are a number of ideas that staff members form about other cultures, in their working environment. Following these considerations, it was revealed which culture prevails in the staff or what culture is more interesting and colourful. According to the results of the question asked, both hotel staffs prefer European culture. This is explained by the fact that people of European nations have greater ability to communicate, are more relaxed and restrained, and have a higher level of service culture.

\section{Conclusion}

The fact that the concept of innovation has become more and more involved in our lives has undoubtedly been realized by the effect of external environmental conditions. It is no longer necessary to say that competitive conditions and customer needs change rapidly. As in many other activities, the impact of organizational culture on innovation activity is twofold.

That is, it can both facilitate and prevent the realization of the activities. In terms of innovation activity, it is clear that not all features of organizational culture will have an impact on innovation. At this point, a subculture, which is the sum of the characteristics of the organizational culture that is related to the activity of innovation, emerges, which is the culture of innovation.

This article seeks to review the literature on cultural diversity and innovation performance. We have tried to cover studies that influence cultural diversity, directly or indirectly, on innovation.

Cultural diversity within the enterprise is manifested in two aspects. The first of these is the presence of foreign nationals within the enterprise, and the second is the provision of services to foreign nationals. In the first case, the effect of diversity is directly on the company. Thus, the work of employees of different nationalities in one enterprise contributes to a richer and more organized organization of the business process. Representatives from different nationalities add their own ideas to the 


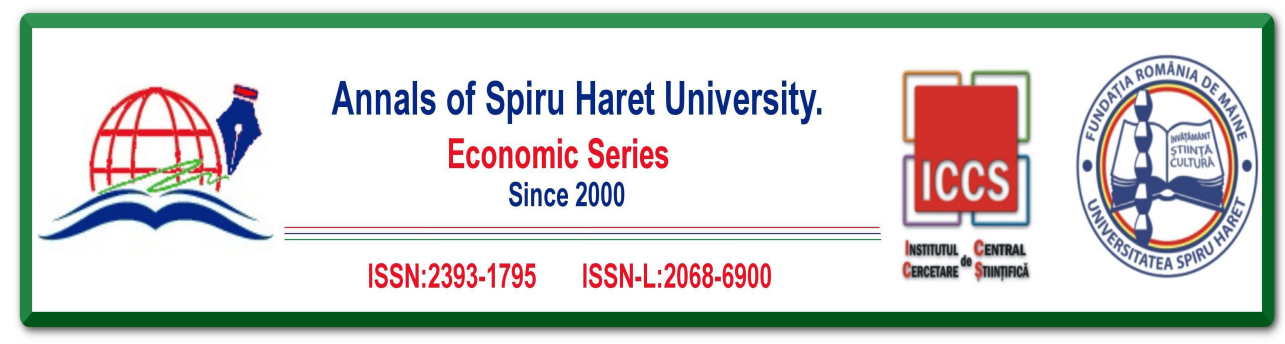

Issue 4/2019

workflow, and as a result, the viewer is different from the member of the nation involved. Finding a common point and pursuing a service or consumption based on it will contribute to the success of an enterprise. Adapting staff to different members is also a time-consuming process.

In the second case, the effect of diversity on intra-organizational processes is immediate. The main affected person here is the employee. When working with a foreigner, staff members can be affected, both positively and negatively. The use of a developing employee's resources (language knowledge, cultural differences, different perspectives, etc.) varies depending on his or her level of creativity. This is why the second aspect is indirect. It is clear from the study that workers have a hard time identifying and preventing problems that may be present due to differences. This curve must be alerted to every possible occurrence of the employee to avoid problems. For this purpose, it would be advisable for employees to study diversity and cross-cultural management fields.

Cultural differences are the biggest challenge for firms, but research shows there is also the potential for innovation. How to solve intercultural problems or use the benefits of cultural heterogeneity is a long-term focus and work.

The results of this study, which seeks to find an answer to air cultural diversity, have a negative or positive impact on innovation. I tried to determine whether the presence of foreign nationals in local firms could influence innovation activity and that diasporas could play an important role in the development of innovation.

\section{References}

[1] Ahmed, P.K. (1998). "Culture and climate for innovation," European Journal of Innovation Management, Vol. 1, Issue 1, pp. 30-43.

[2] Christensen, C.M. \& Eyring, H. J., The Innovative University: Changing the DNA of Higher Education from the Inside Out. San Francisco: Josey Bass, 2011.

[3] Cox, T.H. \& Blake, S. (1991). "Managing Cultural Diversity: Implications for Organizational Competitiveness," Academy of Management, Vol. 5, No 3, pp. 45-56.

[4] Deshpande, R. \& Webster, F.E. (1989). "Organizational culture and marketing: Defining the research agenda." Journal of Marketing, 53, pp. 3-15.

[5] Dobni, C. B. (2008). "Measuring innovation culture in organizations," European Journal of Innovation Management, pp. 544-552.

[6] Etzkowitz, H., The Triple Helix: University-Industry-Government Innovation in Action. Routledge, London, 2008. 


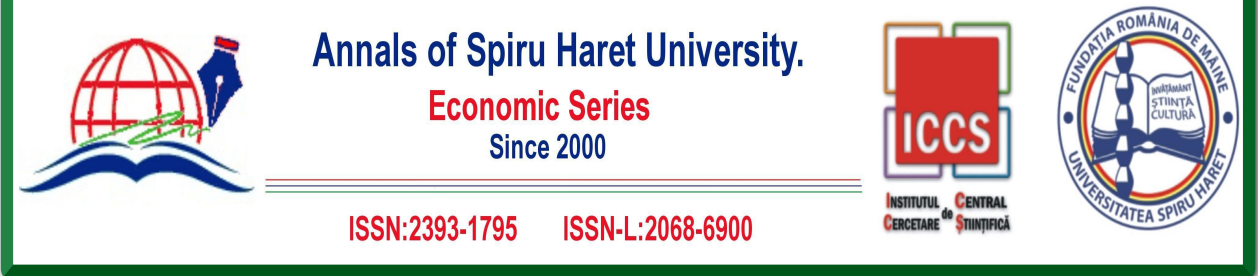

\section{Issue 4/2019}

[7] Fagerberg, J., Innovation: A Guide to the Literature, Oslo University, 2004.

[8] Gandotra, N.K. (2010) "Innovation Culture for sustainable competitive advantage," APJRBM, Volume 1, No. 2, p. 56.

[9] Goffee, R. \& Jones, G. (1996) "What Holds the Modern Company Together?," Harvard Business Review, November-December issue, pp. 133-148.

[10] Gonzales \& Denisi (2009). "Cross-level effects of demography and diversity climate on organizational attachment and firm effectiveness," Journal of Organizational Behavior, January, pp. 21-40.

[11] Hofstede, G., Culture's Consequences: International Differences in Work-Related Values. Beverly Hills, CA: Sage, 1980.

[12] https://globeproject.com/study_2004_2007

[13] Itkin, D., Geva-Kleinberger, A., Yaalon, D.H., Shaanan, U., Goldfus, H. (2012). Nāri in the Levant: Historical and etymological aspects of a specific calcrete formation. Earth Sci. Hist. 31, 210-228.

[14] Kaasa, A., \& Vadi M., How does culture contribute to innovation? Evidence from European Countries, 2008.

[15] Kilmann, R.H. (1985). "Corporate Culture: Managing the Intangible Style of Corporate Life May Be the Key to Avoiding Stagnation," Psychology today, vol. 19(4):62-28, May, pp. 64-67.

[16] Kirby, K.N., \& Marakovic, N.N. (1996). "Delay-discounting probabilistic rewards: rates decrease as amounts increase." Psychological Bulletin Review, pp. 100-104.

[17] Levitt, T. (1960). "Marketing Myopia." Harvard Business Review, səh. 38, pp. 45-56.

[18] Myers, M.D. Qualitative Research in Business \& Management. Sage, London, 2009.

[19] Nielsen, S. (2010). "Top Management Team Diversity: A Review of Theories and Methodologies", 02 August, pp. 42-48.

[20] Osterloh, M. \& Frey, B.S. (2000). "Motivation, Knowledge Transfer, and Organizational Forms," Organization Science, Vol. 11(5), October, pp. 535-550.

[21] Richards, J.B., Zhang, L., Mitchell, S., \& de Wit, H. (1999). "Delay and probability discounting in a model of impulsive behavior: effect of alcohol." Journal of the Experimental Analysis of Behavior, p. 71.

[22] Robbins, S. P., Coulter, M., Pearson, K., Management, 2012, pp. 146-167.

[23] Romer, P. M. (1990a). "Endogenous Technological Change," Journal of Political Economy 98, pp. 71-102.

[24] Schumpeter, J.A. (1934). "The theory of economic development: an inquiry into profits, capital, credit, interest and the business cycle," Harvard Economic Studies, Vol. 46, Harvard College, Cambridge, MA. p. 11.

[25] Schumpeter, J.A., Capitalism, Socialism, and Democracy, 3rd Edition, 1962.

[26] Shane, S.A., Cultural differences in innovation championing strategies, 1992. 


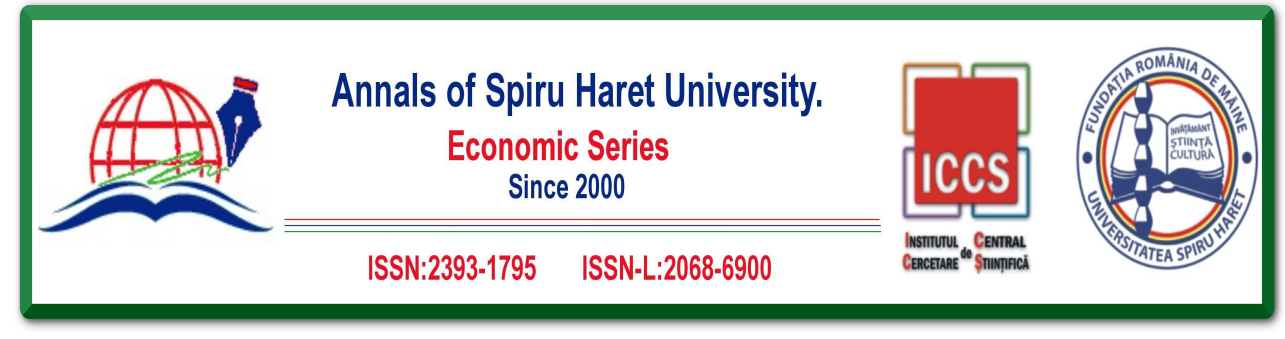

Issue 4/2019

[27] Varga, Z. (1998). Die Erebien der Balkanhalbinsel und Karpaten IV. Übersicht der subspezifischen Gliederung und der Verbreitung der Erebia-Arten in der Balkanhalbinsel und in den Karpaten I. (Lepidoptera, Nymphalidae, Satyrinae). Entomologica romanica 3: 13-29

[28] Wiener, Y., \& Vardi, Y. (1990). "Relationships between Organizational Culture and Individual Motivation - A Conceptual Integration,” August 1, pp. 72-81. 
